\title{
EFFECTS OF DIETARY MORINGA OLEIFERA LEAVES AND LIVE YEAST SUPPLEMENTATION ON NUTRIENT DIGESTIBILITY, NUTRITIVE VALUE AND RUMEN FERMENTATION IN SHEEP
}

\author{
M. M. Farghaly ${ }^{1}$, E. H. Hassan ${ }^{2}$ and W.K. Abouamra ${ }^{2}$ \\ 1- Department of Animal Production, Faculty of Agriculture, Assiut University \\ 2- Department of Animal Production, Faculty of Agriculture, Al-Azhir University, Assuit
}

\section{SUMMARY}

$\mathrm{T}$ his study investigated the impacts of dietary Moringa Oleifera leaves (MOL) and yeast culture (YC) (Saccharomyces cerevisiae) supplementation on nutrient digestibility, feeding value and rumen fermentation in sheep. Four digestibility trials were carried out using four healthy mature Saidi rams were used for each trail as 4x4 Latin square. Each trial lasted for three weeks, the first two weeks were considered as a preliminary period followed by one week collection period. The groups were a control group fed basal diet without supplement and treated groups fed $\mathrm{MO}, 2.5 \%$ of concentrate mixture (T1), $\mathrm{YC}, 0.5 \%$ of concentrate mixture (T2) and 2.5\% MOL $+0.5 \% \mathrm{YC}$ of concentrate mixture (T3). All of Moringa leaves or yeast culture (YC) was mixed with concentrate diet. All animals were fed $60 \%$ of their requirements as DM, concentrate mixture while, wheat straw was given as roughages ad libitum. The experimental design was Latin square model. The data were statistically analyzed using general linear model (G.L.M) procedure of S.A.S (2001) program, version 8.2. The results referred that, the digestibility of dry matter, organic matter, crude protein, crude fibre and ether extract were improved $(\mathrm{P}<0.05)$ for $\mathrm{T} 3$ diet compared with control diet. However, no significant differences were found between $\mathrm{T} 1$ and $\mathrm{T} 2$ diets or between T2 and T3 diets. Also, the feeding value expressed as total digestible nutrient (TDN), digestible crude protein (DCP) and digestible energy (DE) were higher for T2 and T3 diets than T1 and control diets. No significant differences were observed in ruminal $\mathrm{pH}$ among groups. Supplementation of Moringa leaves with live yeast culture to concentrate diet (T3) increased ( $\mathrm{P}<0.05)$ rumen ammonia nitrogen as compared with other groups. However, the volatile fatty acids (VFAs) was higher $(\mathrm{P}<0.05)$ with supplement $\mathrm{YC}$ to concentrate diet group $(\mathrm{T} 2)$ than other groups. The total bacteria count in rumen liquid was higher $(\mathrm{P}<0.05)$ in yeast group $(\mathrm{T} 2)$ than other groups. Also, all treated groups were higher in total bacteria count than control one. In conclusion, dietary supplementation of Moringa leaves and live yeast culture $(S$. cerevisiae) to concentrate mixture may improve nutrient digestibility and rumen fermentation patterns in sheep.

Keywords: Moringa Oleifera leaves, yeast culture, sheep, nutrient digestibility, rumen fermentation

\section{INTRODUCTION}

Feed added substances are a group of feed ingredients that are required in minute quantity and may improve animal nutrition and its profits.

Moringa oleifera leaves can be used as a protein supplement for human being and animals due to its high protein concentration. Moringa oleifera leaves are unique because of their tremendous amounts of minerals and low harmful compound or not toxic. Moringa oleifera leaves meal are good feed sources for livestock, fish, rabbits, laying hens, broiler chickens, growing sheep, and cross-bred cows (Afuang et al., 2003). Recently, several types of research have been investigating the use of $M$. oleifera leaf as a protein source and feed components in animal production especially in goats, (Babeker and Abdalbagi, 2015; Sultana et al., 2015) and sheep (Adegun et al., 2011)). The advantages of using Moringa as livestock feeds include the following: the leaves are rich in minerals which are essential for animal growth and milk production (Mendieta-Araica et al. 2011) and an excellent source of proteins that required for ruminal microbial protein synthesis (Soliva et al. 2005).

Yeast is consider one of the cheapest feed additives that added to sheep rations to improve animal performance and rumen parameters (Farghaly and Hamdon, 2018). Kamra and Pathak (2005) reviewed that YC stimulates microbial growth, increase ruminal $\mathrm{pH}$ and fermentation consequently VFA's production. 


\section{Farghaly et al.}

They added that, dietary yeast culture may improve post ruminal digestion, nutrient digestibility and immune response. Similarly, Garg (2008) found improved nutrients digestibility and increased production of carboxy methyl cellulase activity in the rumen due to dietary YC supplementation. Inclusion of YC in ruminants' diet and non-ruminants leads to improve health status and productivity of animals Calsamiglia et al. (2006). Yeast cells are known to be a rich source of vitamins, enzymes and some unidentified cofactors that are helpful in increasing microbial activity in the rumen (Dawson et al., 1990).

The objectives of our study were to evaluate the effect of dietary Moringa Oleifera leaves (MOL) and yeast culture (YC) (Saccharomyces cerevisiae) supplementation on nutrient digestibility, feeding value and rumen fermentation.

\section{MATERIAL AND METHODS.}

This experiment was carried out at the Animal Production Research Farm, Faculty of Agriculture, AlAzhar University, Assiut branch.

\section{Animals, management and feeding}

Four digestibility trials were conducted on four healthy mature Saidi rams for each trail as $4 \times 4$ Latin square. The age of rams was two years old and a body weight of about $50 \mathrm{~kg}$. The rams were housed individually in metabolic cages and had free access to water throughout the experiment. The trial lasted for 22-days; the first 15 -days were considered as a preliminary period followed by a 7-days fecal collection period. The animals in group one were considered as a control, which was fed a basal diet consisting of concentrate mixture and wheat straw. The second group (T1) rams was fed 2.5\% MOL of concentrate mixture, the third one (T2) received the same basal diet plus $0.5 \% \mathrm{YC}$ of concentrate mixture and the last one (T3) rams received $2.5 \% \mathrm{MOL}+0.5 \% \mathrm{YC}$ to concentrate mixture. The rations were formulated to satisfy the nutrient requirements of rams according to NRC (1985). The rams were fed $60 \%$ of their requirements as a concentrate mixture based on NRC guidelines and the rest were covered from wheat straw as roughages $a d$ libitum. The concentrate mixture, wheat straw, moringa leaves, yeast culture and experimental diets were analyzed chemically for nutrient contents according to AOAC (2005) and are shown in Tables (1) and (2).

\section{Chemical analysis and digestion coefficients measurements}

During the collection period of feces, the daily feed intake of concentrate mixture and wheat straw was calculated by removal of residual feed from the offered one. Samples of diets were taken, mixed and ground through $1 \mathrm{~mm}$ screen and stored for chemical analyses. Feces were collected daily and $10 \%$ of its weight were taken and dried at $60-70{ }^{\circ} \mathrm{C}$ for $24 \mathrm{hrs}$. The fecal samples from each animal were composited and grounded through a $1 \mathrm{~mm}$ mill screen for subsequent chemical analysis. The chemical analyses of feed samples, and feces were carried out by using the methods of AOAC (2005).The apparent digestion coefficients of nutrients were calculated by expressing the difference between the content of nutrients in both consumed feed and feces as a percentage of its intake. The feeding value expressed as total digestible nutrient (TDN), digestible crude protein (DCP) and starch equivalent (SE) were calculated using the chemical analyses of used ingredients and the apparent digestibility rates of different nutrients in the consumed diets according to McDonald et al. (1978). Gross energy (GE), digestible energy (DE) and metabolic energy (ME) were calculated according to Maaf. (1975).

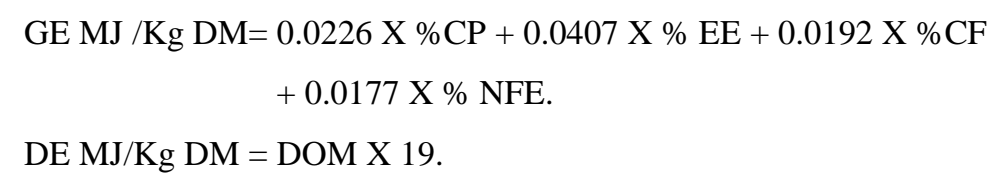

$\mathrm{ME} \mathrm{MJ} / \mathrm{Kg} \mathrm{DM}=\mathrm{DE} \mathrm{X} 0.82$.

\section{Rumen liquor parameters}

At the end of digestibility trial, samples of rumen contents were collected three times from each ram using a stomach tube. Rumen liquor samples were collected 3-4 hrs. after the morning feeding then three and six-hours post feeding. Rumen liquor samples were filtrates through four layers of cheesecloth. The filtrate portion was used immediately for measurement of $\mathrm{pH}$ using a digital $\mathrm{pH}$ meter (Beckman, model 45, USA). Ammonia $\mathrm{N}$ concentration in rumen liquor was determined according to Chibnal and Williams 
(1943). Strained rumen liquor samples were acidified with $0.1 \mathrm{~N}$ hydrochloric acid and concentrated orthophosphoric acid to stop the microbial activity before its storage for analysis, and then the samples were kept frozen at $-20^{\circ} \mathrm{C}$ for determination of total volatile fatty acids (VFAs) and total bacteria count. The concentration of TVFA's was determined by the steam distillation method (Warner, 1964) using Markham micro distillation apparatus. The total bacteria count was determined according to Bryant and Turkey (1953).

Table (1): Chemical composition (\%) of concentrate mixture, wheat straw, Moringa leaves and yeast culture (on DM basis).

\begin{tabular}{lcccc}
\hline Item & $\begin{array}{c}\text { Concentrate } \\
\text { mixture }\end{array}$ & Wheat straw & $\begin{array}{c}\text { Moringa } \\
\text { leaves }\end{array}$ & Yeast culture \\
\hline Dry matter (DM) & 89.80 & 93.12 & 90.83 & 91.66 \\
Organic matter (OM) & 87.88 & 89.20 & 89.85 & 97.72 \\
Crude protein (CP) & 13.95 & 1.79 & 21.51 & 37.83 \\
Crude fiber (CF) & 20.10 & 39.71 & 4.65 & 8.44 \\
Ether extract (EE) & 3.20 & 0.45 & 5.69 & 4.51 \\
Nitrogen free extract (NFE) & 50.60 & 47.25 & 58 & 46.94 \\
Ash & 12.12 & 10.80 & 10.15 & 2.03 \\
Gross energy (MJ /Kg DM) & 1.73 & 1.69 & 1.83 & 2.03 \\
\hline
\end{tabular}

Table (2). Chemical analysis and nutrient composition of experimental diets (\% on DM basis)

\begin{tabular}{lcccc}
\hline \multirow{2}{*}{ Item } & \multicolumn{4}{c}{ Treatment } \\
\cline { 2 - 5 } & Control & T1 & T2 & T3 \\
\hline Dry matter (DM) & 90.77 & 90.95 & 90.80 & 90.76 \\
Organic matter (OM) & 88.27 & 88.73 & 88.29 & 88.32 \\
Crude protein (CP) & 10.39 & 9.95 & 10.38 & 10.73 \\
Crude fiber (CF) & 25.84 & 26.50 & 25.93 & 25.32 \\
Ether extract (EE) & 2.40 & 2.31 & 2.36 & 2.47 \\
Nitrogen free extract (NFE) & 50.60 & 47.25 & 58.00 & 46.94 \\
Ash & 11.73 & 11.63 & 11.71 & 11.68 \\
Gross energy (MJ /Kg DM) & 1.71 & 1.71 & 1.71 & 1.71 \\
\hline
\end{tabular}

T1: rams received $2.5 \%$ Moringa leaves; T2: rams received $0.5 \%$ yeast culture; T3 rams received $2.5 \%$ Moringa leaves $+0.5 \%$ yeast culture

\section{Statistical Analysis:}

The experimental design was Latin square model. The data were statistically analyzed using general linear model (G.L.M) procedure of S.A.S (2001) program, version 8.2. Differences between groups in digestibility and nutritive values were evaluated by one-way ANOVA. The significant differences between treatments means were tested by Duncan Multiple Range Test (Steel and Torrie, 1980). The data are presented as means \pm SE. Probability values of less than $0.05(\mathrm{P}<0.05)$ were considered to be significant. The following model was used, 


\section{Farghaly et al.}

$$
Y_{i j}=\mu+T_{i}+E_{i j}
$$

The Rumen liquid parameters data was analyzed according to the following statistical model.

$$
\mathrm{Y}_{\mathrm{ijk}}=\mu+\mathrm{T}_{\mathrm{i}}+\mathrm{M}_{\mathrm{j}}+(\mathrm{TM})_{\mathrm{j}}+\mathrm{E}_{\mathrm{ijk}}
$$

Where, $Y_{i j}=$ experimental observation, $\mu=$ general mean, $T_{i}=$ the effect of treatment, $i=$ control $, T 1, T 2$, $\mathrm{T} 3, \mathrm{E}_{\mathrm{ij}}=$ the errors related to individual observation, $\mathrm{M}_{\mathrm{j}}=$ the effect of time sampling after feeding, $\mathrm{j}=$ zero, three hours and six hours, $(\mathrm{TM})_{\mathrm{j}}=$ interactions between time and treatment

\section{RESULTS AND DUSSCTION}

\section{Nutrient digestibility coefficients}

The effects of supplemented MOL and YC or its combination on nutrients digestibilities are shown in Table (3). Dietary MOL (T1) had no effect on all nutrients digestibility's with exception of CF digestibility, which improved $(\mathrm{P}<0.05)$ by $7.5 \%$ in favor of MOL diet group. Similar result was found by Adeniji et al. (2010), they stated that digestibility of nutrients was not affected by using moringa leaves in rabbits' diet. However, Tonia et al. (2014) found that goats fed the concentrate diet with 15\% of Moringa oleifera leaf meal had significantly higher rate of digestibility coefficients than those fed $5 \%$ or $10 \%$ inclusion level. The improvement CF digestibility in T1 of moringa leaves diet may be due to increase of fibrolytic bacteria in the rumen. Fayomi et al. (2014) attributed the higher CF digestibility with increasing MOL level from 7 to 9\% in diets of sheep to increase activities of fibrolytic bacteria in the rumen due to the increase of available essential nutrients especially protein, energy and minerals in balanced proportions and /or enhanced microbial growth and multiplication. Also, CP and EE digestibility in T1 group were numerically improved by 5.3 and $6.2 \%$, respectively compared to control group. This is probably because Moringa leaves consists of more degradable components especially crude protein and this could serve as supplement to ruminant diets (Fayomi et al., 2014). Nuhu (2010) stated that feeding Moringa oleifera dry leaves was improving CP digestibility on rabbits.

Table (3). Effect of Moringa leaves and yeast culture supplement to ram's ration on nutrient

\begin{tabular}{|c|c|c|c|c|c|}
\hline \multirow{2}{*}{ Item } & \multicolumn{4}{|c|}{ Treatment } & \multirow{2}{*}{$P$ value } \\
\hline & Control & $\mathrm{T} 1$ & $\mathrm{~T} 2$ & T3 & \\
\hline$\overline{\mathrm{DM}}$ & $69.11^{b} \pm 0.74$ & $72.01^{\mathrm{ab}} \pm 2.58$ & $75.29^{\mathrm{a}} \pm 1.19$ & $74.96^{\mathrm{a}} \pm 0.65$ & 0.031 \\
\hline OM & $70.63^{b} \pm 0.76$ & $73.45^{\mathrm{ab}} \pm 2.73$ & $76.43^{\mathrm{a}} \pm 1.23$ & $76.06^{\mathrm{a}} \pm 0.55$ & 0.048 \\
\hline $\mathrm{CP}$ & $64.10^{c} \pm 1.94$ & $67.66^{b c} \pm 3.72$ & $75.07^{\mathrm{ab}} \pm 2.12$ & $76.50^{\mathrm{a}} \pm 0.77$ & 0.017 \\
\hline $\mathrm{CF}$ & $71.90^{b} \pm 2.07$ & $77.71^{\mathrm{a}} \pm 1.77$ & $78.88^{\mathrm{a}} \pm 0.71$ & $82.03^{\mathrm{a}} \pm 0.43$ & 0.006 \\
\hline $\mathrm{EE}$ & $60.58^{b} \pm 2.58$ & $64.59^{\mathrm{ab}} \pm 3.39$ & $70.05^{\mathrm{a}} \pm 1.78$ & $71.36^{\mathrm{a}} \pm 0.43$ & 0.043 \\
\hline NFE & $71.68 \pm 0.52$ & $72.59 \pm 3.16$ & $75.98 \pm 1.49$ & $73.32 \pm 0.58$ & 0.414 \\
\hline
\end{tabular}
digestibility, \%

${ }^{a, b, c}$ Values in the same row with different superscripts differ significantly $(p<0.05)$.

T1: rams received 2.5\% Moringa leaves; T2: rams received 0.5\% yeast culture; T3 rams received $2.5 \%$ Moringa leaves $+0.5 \%$ yeast culture

Supplement yeast culture alone in T2 diet or combined with MOL in T3 diet increased $(\mathrm{P}<0.05)$ the digestibility's of dry matter (DM), organic matter $(\mathrm{OM})$, crude protein $(\mathrm{CP})$, crude fibre $(\mathrm{CF})$ and ether extract (EE) compared with control diet (Table 3). Moreover, no significant differences were found between $\mathrm{T} 1$ and T2 or between T2 and T3. The improvement all nutrients digestibilities with supplement yeast culture to concentrate mixture may be due to the stimulation of rumen proteolytic bacteria and protozoa. Also, the improve CF digestibility in T2 and T3 in the present study may be explained on the basis of increasing the number of rumen cellulolytic bacteria due to yeast culture supplementation (Farghaly and Hamdon, 2018). Newbold et al. (2000) found that dietary yeast increased the breakdown of fiber in the rumen, which increased microbial protein production, consequently, more protein available for absorption in the small intestine. Ghazanfar et al. (2015) attributed the improvement in nutrients digestibility to the 
increase of cellulose degrading microbial biomass population inside rumen. Similar results were reported by Helal and Abdel-Rahman (2010), they found that sheep fed diets supplemented with yeast culture had higher nutrients digestibilities than those of control diet.

\section{Feeding value}

The feeding value in terms of total digestible nutrients (TDN), starch equivalent (SE), digestible crude protein (DCP), digestible energy, and metabolic energy (ME) of $\mathrm{T} 2$ and $\mathrm{T} 3$ groups were higher $(\mathrm{P}<0.05)$ than control group (Table 4). However, no significant differences were found between T1 and control or between T2 and T3 groups. The improvement nutritive value with supplement yeast culture to T2 ration or combined it with Moringa leaves in T3 ration may be due to improvement in nutrients digestibilities (Table 3). This results were confirmed by Khattab et al. (2010) found that digestibility and feeding value of buffaloes ration were improved $(\mathrm{P}<0.05)$ as a result of supplement dried yeast (Saccharomyces cerevsiae). Farghaly and Hamdon (2018) found that the feeding values in terms of total digestible nutrients (TDN), starch value (SV) and digestible crude protein (DCP) increased with supplement yeast culture at levels of 0.5 and $1 \%$ in the diets of rams. Similarly, Komonna (2007) and Helal and Abdel-Rahman (2010) they reported that yeast culture and commercial probiotic tended to improve TDN and DCP. Robinson (1997) stated that yeast culture supplementation increased the digestibility of fiber leading to improve energy output.

\section{Total bacteria count in rumen}

Data in table (4) shown that the total bacteria count in rumen liquid was higher $(\mathrm{P}<0.05)$ in yeast group (T2) than other groups. Also, all treated groups were higher in total bacteria count than control one. The elevated number of bacteria in the rumen of YC supplemented animals may be due to the yeast cells contains several vitamins, enzymes, organic acids and some unknown cofactors that may enhance growth of rumen microbes ( Chaucheyras e al.,1995). This results agreement with Farghaly and Hamdon (2018), they reported that the total bacterial and protozoal count were increased $(\mathrm{P}<0.05)$ in the rumen with increasing the level of yeast culture in diets of sheep from 0.5 to $1 \%$ as compared with control one. Similarly, Chaucheyras-Durand et al. (2005) reported that the number of cellulolytic bacteria and protozoa increased in newborn lambs supplemented with yeast culture by using stomach tube. Also, Sarwatt et al. (2004) reported that the small amounts of Moringa leaves improved the rumen environment, which leads to the increase of microorganisms in the rumen.

Table (4): Effect of Moringa leaves and yeast culture supplement on nutritive values and total bacteria count in rumen of experimental rations.

\begin{tabular}{|c|c|c|c|c|c|}
\hline \multirow{2}{*}{ Item } & \multicolumn{4}{|c|}{ Treatment } & \multirow{2}{*}{$\begin{array}{c}\mathrm{P} \\
\text { value }\end{array}$} \\
\hline & Control & $\mathrm{T} 1$ & $\mathrm{~T} 2$ & T3 & \\
\hline TDN, \% & $64.093^{b} \pm 0.608$ & $66.90^{\mathrm{ab}} \pm 2.55$ & $69.673^{\mathrm{a}} \pm 1.181$ & $69.470^{\mathrm{a}} \pm 0.504$ & 0.041 \\
\hline $\mathrm{DCP}, \%$ & $6.660^{\mathrm{b}} \pm 0.202$ & $6.736^{\mathrm{b}} \pm 0.402$ & $7.796^{\mathrm{a}} \pm 0.346$ & $8.213^{\mathrm{a}} \pm 0.131$ & 0.012 \\
\hline $\mathrm{SV}, \%$ & $41.596^{\mathrm{b}} \pm 0.624$ & $43.196^{\mathrm{ab}} \pm 2.620$ & $47.043^{\mathrm{a}} \pm 1.384$ & $47.540^{\mathrm{a}} \pm 0.750$ & 0.040 \\
\hline $\mathrm{DE}, \mathrm{MJ} / \mathrm{kg} \mathrm{DM}$ & $1184.48^{\mathrm{b}} \pm 13.482$ & $1233.04^{\mathrm{ab}} \pm 45.669$ & $1282.36^{\mathrm{a}} \pm 20.487$ & $1276.25^{\mathrm{a}} \pm 8.934$ & 0.036 \\
\hline ME,MJ/kg DM & $947.94^{\mathrm{b}} \pm 12.765$ & $1011.10^{\mathrm{ab}} \pm 37.450$ & $1051.54^{\mathrm{a}} \pm 16.800$ & $1046.66^{\mathrm{a}} \pm 7.470$ & 0.033 \\
\hline $\begin{array}{l}\text { Total bacteria } \\
\text { count }\left(\text { x } 10^{4} / \mathrm{mL}\right)\end{array}$ & $3.81^{\mathrm{c}} \pm 0.062$ & $4.38^{\mathrm{b}} \pm 020$ & $5.15^{\mathrm{a}} \pm 0.039$ & $4.42^{\mathrm{b}} \pm 0.026$ & 0.001 \\
\hline
\end{tabular}

\section{Rumen parameters.}

Data of ruminal pH, NH3-N and TVFA's concentration are presented in Table (5). Results indicated that the rumen $\mathrm{pH}$ values were not significantly different among groups. These results are in agreement with those reported by Al-Dabeeb and Ahmed (2002), Ali (2005), Komonna (2007) and (Galip, 2006), they reported that yeast culture or commercial probiotic had no effect on ruminal pH. Also, Kewan et al. (2019) showed that no differences were observed among experimental rations contained moringa with yeast or fungi on rumen $\mathrm{pH}$. However, Abdel-Khalek et al. (2000) found that the rumen $\mathrm{pH}$ value decrease with the addition of yeast culture to ration of suckling Friesian calves. 


\section{Farghaly et al.}

Concerning the effect of sampling time on ruminal $\mathrm{pH}$, the mean values of $\mathrm{pH}$ were lower $(\mathrm{P}<0.05)$ at 3 hrs. and $6 \mathrm{hrs}$. after feeding than before feeding. The decrease in ruminal $\mathrm{pH}$ after feeding could be linked to the increase of VFA concentration (Table 5). Huard et al. (1998) reported that rumen $\mathrm{pH}$ was negatively correlated with total VFA $(\mathrm{r}=-0.60 ; \mathrm{P}<0.001)$, indicating that $36 \%$ of the variation in rumen $\mathrm{pH}$ was due to VFA production. Similarly, Owens et al. (1998) concluded that rumen $\mathrm{pH}$ is affected by TVFA's concentration in rumen fluid as results of intensive fermentation process of both nonstructural and structural carbohydrates and the production of volatile fatty acids. The results of the present study

Table (5) Effect of Moringa leaves and yeast culture supplement on rumen parameters.

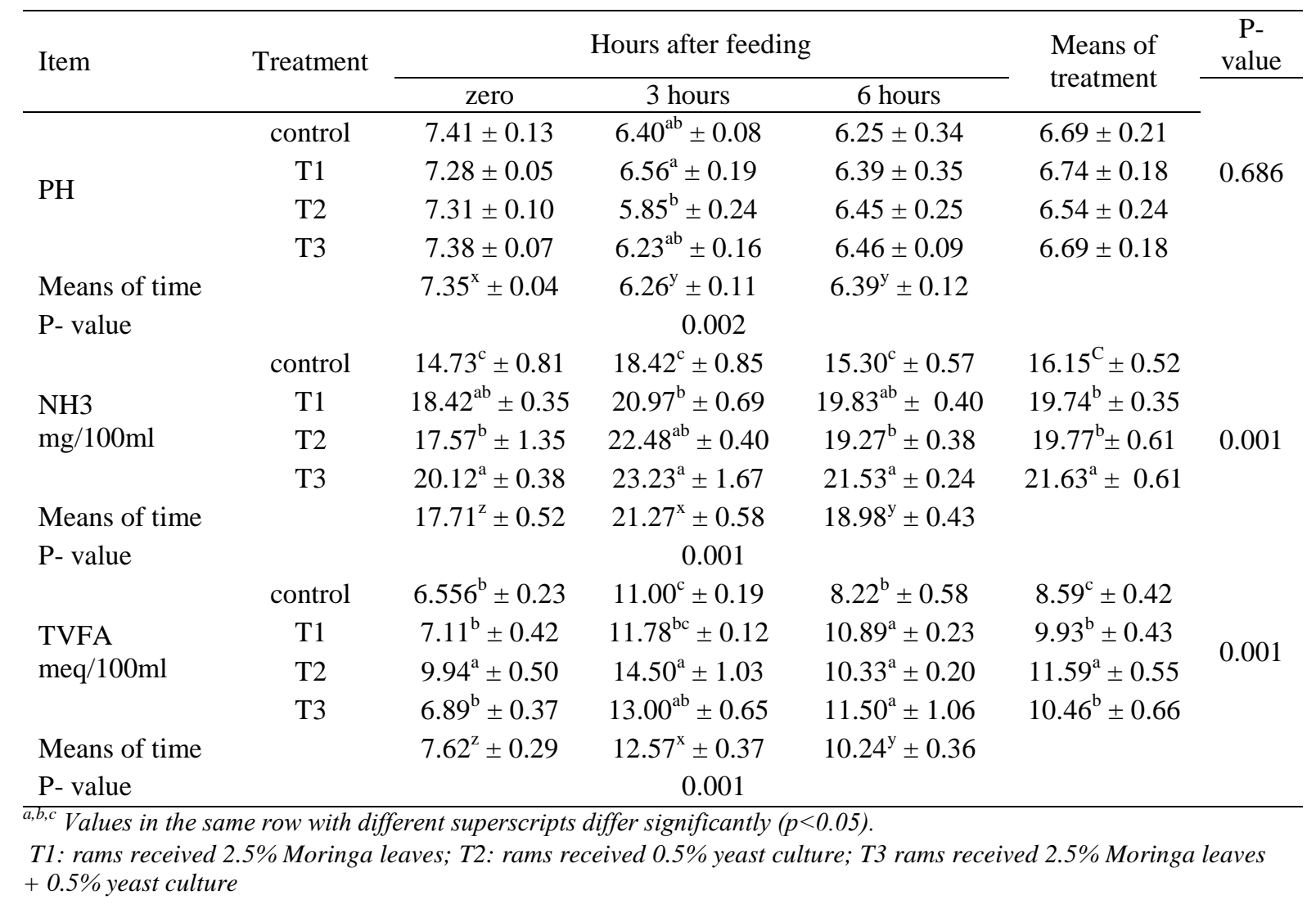

demonstrated that ammonia NH3-N concentration was higher $(\mathrm{P}<0.05)$ in the rumen of lambs fed on T3 ration than other groups. Also, NH3-N concentration was increased $(\mathrm{P}<0.05)$ with $\mathrm{T} 2$ and $\mathrm{T} 1$ as compared to control group. The ammonia NH3-N concentration in this study was within the normal range as described by Church (1976), being 10 to $45 \mathrm{mg} / 100 \mathrm{ml}$ depending on composition of the ration, time of sampling and method of analysis used. Ammonia production in the rumen is a result of two metabolic processes, a direct protein degradation by the microbial proteases (Parker et al., 1995) and recycled $\mathrm{N}$ via saliva and blood through the rumen wall (Seal and Reynolds, 1993). Rumen $\mathrm{NH}_{3}$ would rapidly accumulate in the rumen if the release of energy for microbial activity from available carbohydrates was not coupled with the release of $\mathrm{NH}_{3}$ in the early hours after feed consumption (Nocek and Russell, 1988; Kennedy and Milligan, 1980). Yadov and Yadav (1988) reported that increased ruminal NH3-N concentration might be due to the higher N intake and higher $\mathrm{CP}$ digestibility (Table 5). The higher ammonia concentration with addition moringa leaves and yeast culture was agreement with Galip (2006), who reported that ruminal ammonia-N concentrations was significantly increased by dietary supplement for yeast culture whatever the ratio forage/concentrate of the diet. On the other hand, kholif et al. (2015) attributed the lower ruminal ammonia$\mathrm{N}$ concentration with Moringa oleifera leaves fed goats due to the lower protein degradability of Moringa in the rumen. Also, Soliva et al. (2005) found that the ruminal ammonia-N concentration was lower with dietary M. oleifera leaves than with were than soybean and rapeseed meal. 
Effect of sampling times on $\mathrm{NH}_{3}-\mathrm{N}$ concentration showed a cubic effect, which the mean values of $\mathrm{NH}_{3}$ $\mathrm{N}$ concentration were lower before feeding and increased after feeding to reach the peak at $3 \mathrm{hrs}$ post feeding and then decrease again at $6 \mathrm{hrs}$ after feeding. Kewan, et al.(2019) found that the lambs fed ration continuing Moringa oleifera tree stalks treated with yeast showed higher $(\mathrm{P}<0.05)$ rumen $\mathrm{NH} 3-\mathrm{N}$ concentrations at $3 \mathrm{hrs}$. after feeding compared with at zero time and $6 \mathrm{hrs}$. after feeding. The Moringa yeast ration contained higher soluble plant protein which led to the production of large quantities of NH3-N in excess of the requirements of rumen microorganisms and were converted to urea in the liver and excreted in urine. The microbial population in the rumen requires a minimum level of ammonia $(70 \mathrm{gm} / \mathrm{l})$ to support optimum activity (Ahn, 1990).

The ruminal total VFA's concentration of T2 was higher $(\mathrm{P}<0.05)$ than that of other group. Also, the ruminal total VFA's of T1 and T3 was increased as compared with control group. The high value of total VFA's in treatment groups may be due to improve nutrients digestibility in this groups as compared with control one. However, the VFAs concentration might be also affected by other factors such as rate of absorption, outflow of the digesta from the rumen to other parts of the digestive tract and activity of the microbial population in the rumen (Allam et al., 1982). This result was confirmed by Kholif et al. (2015), they found that the ruminal TVFA concentration increased with addition Moringa leaves to goats ration. Farghaly and Hamdon (2018) reported that dietary yeast culture supplements to sheep diet at alevel of 0.5 and $1 \%$ increased $(\mathrm{P}<0.05)$ ruminal VFA's concentration and total bacterial and protozoal count. However, Soliva et al. (2005) found that the total VFAs concentration was not affected by MOL supplemented-diet.

Effect of sampling time on total VFAs concentration is presented in Table 5. The mean values of total VFAs concentrations were lower before feeding and increased after feeding to reach the peak at $3 \mathrm{hrs}$ post feeding, then decreased again at $10 \mathrm{hrs}$ post feeding. Kewan et al. (2019) found that the lambs fed rations continuing Moringa oleifera tree stalks treated with yeast or fungi showed gradual increased $(\mathrm{P}<0.05)$ of rumen TVFA's from zero time up to $6 \mathrm{hrs}$. post-feeding.

\section{CONCLUSION}

Dietary yeast culture $(0.5 \%$ of concentrate diet), particularly with moringa leaves $(2.5 \%$ of concentrate diet) may improve nutrients digestibilities, nutritive value and rumen fermentation parameters of sheep.

\section{REFERENCE}

Abdel-Khalek, A. E., A.F., Mehrez, and Omar, E. A., (2000). Effect of yeast culture (Lacto-Sacc) on rumen activity, blood constituents and growth of suckling Friesian calves. Prod. Conf. Anim. Prod. In the 21th century, Sakha, 18 - 20 April : $201-210$.

Adegun, M.K., P.A., Aye., Dairo., F.A.S. (2011). Evaluation of Moringa oleifera, Gliricidiasepium and Leucaena leucocephala-based multi nutrient blocks as feed supplements for sheep in South Western Nigeria. Agric. Biol. J. North Am. 2, 1395-1401.

Adeniji, A.A., E.S., Gana, I.C., Chibuogwu and Onyia, R.U., (2010). The feeding value of Moringa oleifera leaves for growing rabbits, In: Proc. 36 Ann Conf., Nig. Soc. Animal Production (NSAP), March 13-16, 2011, University of Abuja, Nigeria, pp: 610-613.

Afuang, W, P, Siddhuraju, Becker, K (2003). Comparative nutritional evaluation of raw, methanol extracted residues and methanol extracts of Moringa (Moringa oleifera Lam) leaves on growth performance and feed utilization in Nile tilapia (Oreochromis niloticus L). Aquacul Res, 34, 1147-1159.

Ahn, J.H., (1990). Quality assessment of tropical browse legumes : tannin content and nitrogen degradability. Ph.D. Thesis, The University of Queensland, England.

Al-Dabeeb, S. N. and Ahmed, B. M., (2002). Effect of dry yeast (Saccharomyces cerevisiae) in sheep rations differing in their roughage to concentrate ratio on digestion, nitrogen balance and rumen fermentation. Egyptian J. Nutr. And Feeds, 5 (1) : 1 - 11. 


\section{Farghaly et al.}

Ali, M. A., (2005). Effect of probiotic addition on growth performance of growing lambs fed different roughages. Egyptian J. Nutr. and Feeds, 8 (1) Special Issue : 567 -578.

AOAC, (2005). Official Methods of Analysis (16th ed.). Washington, DC: Association of Official Analytical Chemists, USA.

Babeker, E.A., Abdalbagi Y.M., (2015). Effect of feeding different levels of Moringa oleifera leaves. on performance, haematological, biochemical and some physiologica parameters of Sudan Nubian goats. Online J. Anim. Feed Res 5, 50-61.

Bryant, M.P. and L.A. Turkey, (1953).Cultural methods and some characteristics of some of the more numerous groups of bacteria in the bovine rumen. J. Dairy Sci.36:205-217

Calsamiglia, S., L. Castillejos and Busquet, M., (2006). Alternatives to antimicrobial growth promoters in cattle. In Garnworthy, P C, Wiseman, J: Recent Advances in Animal Nutrition, Nottingham p. 129-167.

Chaucheyras-Durand F, Masseglia S, Fonty, G., (2005). Effect of the microbial feed additive Saccharomyces cerevisiae CNCM I-1077 on protein and peptide degrading activities of rumen bacteria grown in vitro. Current Microbiology, 50: 96-101.

Chaucheyras, F, Fonty, G, Bertin G, Gouet, P., (1995). bacterium cultivated alone or in association with an archaea methanogen is stimulated by a probiotic strain of Saccharomyces cerevisiae. probiotic strain of Saccharomyces cerevisiae. Applied Environ. Microbiol. 61: 3466-3467.

Chibnal, A.C., E.F., Williams., and Reese, (1943). The total nitrogen content of egg albumin, and other protein. Biochemical, J.37, 3:354.

Church. D.C., (1976). Digestive Physiology and Nutrition Ruminants, Vol. 1. Digestive Physiology 145. 2nd Ed. 8 Books, Corvallis, Oregan. (C. F. Marei (2007).

Dawson, K. A., K. A. Newman and Boling, J. A., (1990). Effect of microbial supplements containing yeast and lactobacilli on roughage-fed ruminal microbial activities. J. Anim. Sci. 68:3392-3398 .

Farghaly, M. M. and Hamdon, H. A., (2018). Effects of live yeast (saccharomyces cerevisiae) supplementation on nutrient digestibility, rumen fermentation and rumen microbial population count in sheep. Egyptian J . Anim. Prod,. 55(1): 1-6

Fayomi, A., Ahmed, A., Musa, U., Salami-Shinaba, J. O., Ogedegbe, S. A., \& Akanni, K. ,(2014). Moringa multi-nutrient blocks: formulation, production, and feeding trial under a tropical environment. International Journal of Science, Environment and Technology, 3(1), 67-84.

Galip N., (2006) Effect of supplemental yeast culture on ruminal protozoa and blood parameters in rams. Rev. Med. Vet.-Toulouse, 157, 519-524.

Garg, D. D., (2008). Efficiency of utilization of leguminous straw based complete feed blocks alone and in combination with probiotics (Saccharomyces cerevisiae) in ration of sheep. Thesis, submitted to Rajasthan Agricultural University, India

Ghazanfar, S, Anjum M.I, Ahmed AA., (2015). Effects of dietary supplementation of yeast (saccharomyces cerevisiae) culture on growth performance, blood parameters, nutrient digestibility and fecal flora of dairy heifers. J.Anim. Plant Sci. 25(1): 53-59.

Hamdon H. A. and Farghaly M. M., (2016). Improving growth performance and carcass characteristics of lambs as a result caring management via dietary yeast supplementation. Egyptian J. Anim. Prod, 53(2):103-110

Helal, F.I.S. and Abdel- Rahman, K.A., (2010). Productive performance of lactating ewes fed diets supplementing with dry yeast and/or bentonite as feed additives. World J. Agric. Sci. 6(5):489-498.

Huard, S., Petit, H. V., Seoane, J. R., Rioux, R., (1998a). Effects of mechanical treatment of whole canola seeds on performance, diet digestibility and rumen parameters of lambs fed grass silage. Can. J. Anim. Sci. 78, 657-664.

Kamra, D.N., and N.N., Pathak, (2005). Improvement in livestock productivity by use of probiotics: A review. Indian J. Anim. Sci. 75: 128-134. 
Kennedy, P.M., Milligan, L.P., (1980). The degradation and utilization of endogenous urea in the gastrointestinal tract of ruminants: a review. Can. J. Anim. Sci. 60, 205-221.

Kewan, K. Z., Salem, F. A., Salem, A. Z. M., Abdou, A. R., El-Sayed, H. M., Eisa, S. S., and Odongo, N. E., (2019). Nutritive utilization of Moringa oleifera tree stalks treated with fungi and yeast to replace clover hay in growing lambs. Agroforestry systems, 93(1), 161-173.

Khattab, H. M, El-Nor, S. A, Kholif, S. M, El-Sayed, H. M; El-Shaffy, O. A and Saada, M., (2010). Effect of different additive sources on milk yield and composition of lactating buffaloes. Livestock Science, 131(1): 8-14.

Kholif, A. E., G.A., Gouda., T.A. Morsy., A.Z.M. Salem., S., López., and Kholif A.M., (2015). Moringa oleifera leaf meal as a protein source in lactating goat's diets: feed intake, digestibility, ruminal fermentation, milk yield and composition, and its fatty acids profile. Small Ruminant Research, 129, 129137.

Komonna, O.F.A., (2007). Phsiological and nutritional responses of sheep to some feed additives. Ph.D. Thesis, Fac. Agric., Minufiya University.

Maaf, (1975). Ministry of agriculture, fisheries and food energy allowwwwances and feeding system for ruminants.Technical bulletin,99 London,H.M.50.

McDonalds, P., R.A., Edward, J.F.D, Greenhalgh, (1988). Animal Nutrition (4th edition) Longman, U.K.

Mendieta-Araica, B., Spörndly, E., Reyes-Sánchez, N., Spörndly, R., (2011). Feeding Moringa oleifera fresh or ensiled to dairy cows - effects on milkyield and milk flavor. Trop. Anim. Health Prod. 43, 1039-1047.

Newbold, J., (2000). Manipulation of Rumen Fermentation- Yeast Culture. Paper presented at the IV International Seminar Applied Microbiology to Animal Nutrition in Querétaro, Mexico.

Nocek, J.E., Russell, J.B., (1988): Protein and energy as an integrated system. Relationship of ruminal protein and carbohydrate availability to microbial synthesis and milk production. Chaney, A.L., Marbach, E.P., 1962. Modified reagent for de- J. Dairy Sci. 71, 2070-2107.

N.R.C., (1985). Nutrient Requirements of sheep. National Academy of Science. National Research Council, Washington, DC, U.S.A.

Nuhu, F., 2010. Effect of moringa leaf meal (MOLM) on nutrient digestibility, growth, carcass and blood indices of weaner rabbits. M. Sc. Thesis in Animal Nutrition, Kwame Nkrumah University of Science and Technology, Kumasi.

Owens, F. N., Secrits, D. S., Hill, W. J. and Jill, D. R., (1998). Acidosis in cattle: a review. J. Anim. Sci., 76: 275.

Parker, D.S., Lomax, M.A., Seal, C.J., Wilton, J.C., (1995). Metabolic implications of ammonia production in the ruminant.57-72. Proc. Nutr. Soc. 54, 549-563.

Robinson, P. H., (1997). Effect of yeast culture (Saccharomyces cerevisiae) on adaptation of cows to diets postpartum. J. dairy Sci., 80 (6), $1119-1125$.

SAS (2001). Statview for Windows, Version 8.2.SAS Institute, Cary, NC， USA.

Sarwatt, S.V., M.S. Milang'ha, F.P., Lekule and Madalla, N., (2004). Moringa oleifera and cottonseed cake as supplements for smallholder dairy cows fed Napier grass. Livest. Res. Rural Dev., Vol. 16, No. 6.

Seal, C.J., Reynolds, C.K., (1993). Nutritional implications of gastrointestinal and liver metabolism in ruminants. Nutr. Res. Rev. 6, 185-208.

Soliva, C. R., Kreuzer, M., Foidl, N., Foidl, G., Machmuller, A. and Hess, H. D., (2005). Feeding value of whole and extracted Moringa oleifer leaves for ruminants and their effects on ruminal fermentation in vitro. Animal Feed Science and Technology. 118, 47-62.

Steel, R. G. D. and Torrie J. H., (1980). Duncan's new multiple range tests. Principles and procedures of statistics, 187-188. 


\section{Farghaly et al.}

Sultana, N, Alimon, A.R, Huque, KS, Sazili, AQ, Yaakub, H, Hossain, J., (2014). The effect of cutting interval on yield and nutrient composition of different plant fractions of Moringa oleifera tree. Journal of Food Agriculture \& Environment.12(2), 599-604.

Sultana, N., Alimon, A.R., Huque, K.S., Sazili, A.Q., Yaakub, H., Hossain, J., Baba, M., (2015). The feeding value of moringa (Moringa oleifera) foliage as replacement to conventional concentrate diet in Bengal goats. Adv. Anim. Vet. Sci. 3, 164-173.

Tona, G. O., Ogunbosoye, D. O., and Bakare, B. A., (2014). Growth performance and nutrient digestibility of West African Dwarf goats fed graded levels of Moringa oleifera leaf meal. International Journal of Current Microbiology and Applied Sciences, 3(8), 99-106.

Wanner, A.G.T., (1964).Production of volatile fatty acid in the rumen. Methods of measurement. Nutr.Abstr.Rev,34, 339.

Yadov, B.P.S, Yadav, I.S., (1988). Incubation studies with strained rumen liquor of cattle for in vitro evaluation of ammoniated straw. Indian J Anim Sci 58(3):398-402
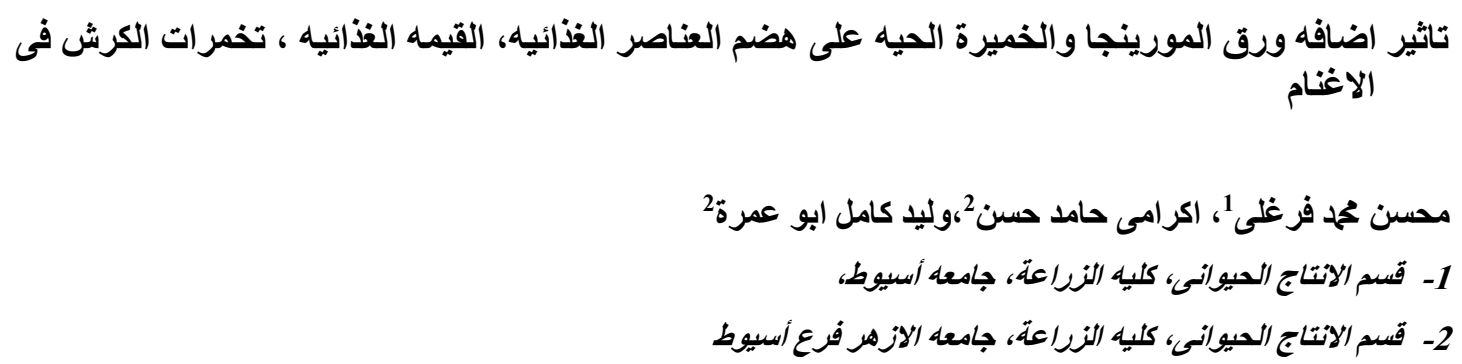

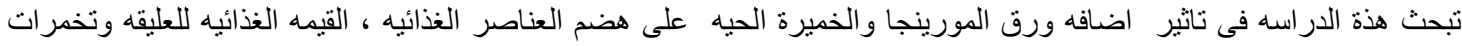

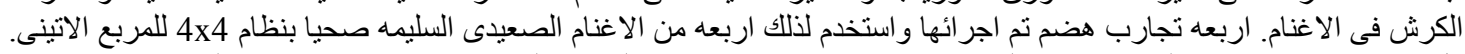

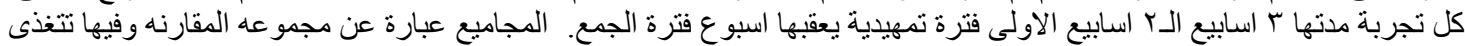

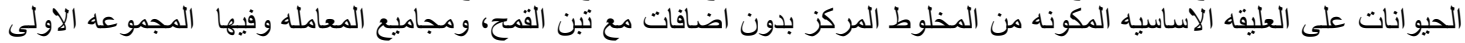

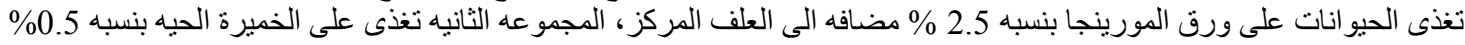

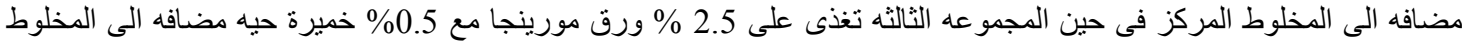

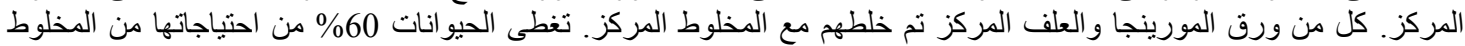

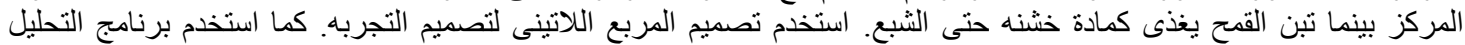

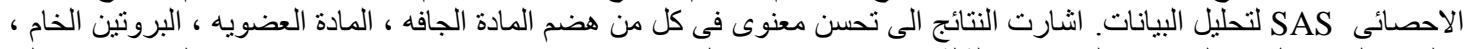

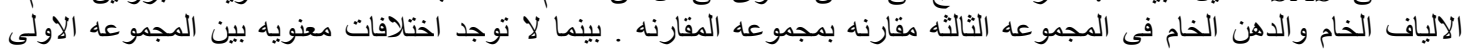

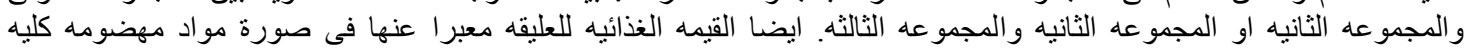

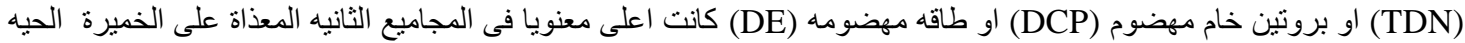

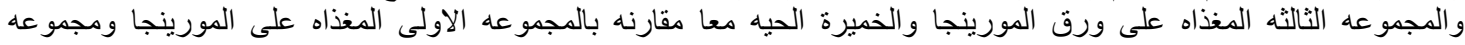

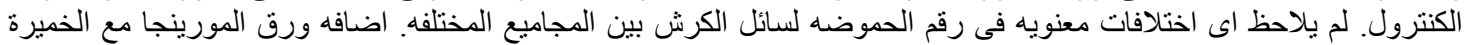

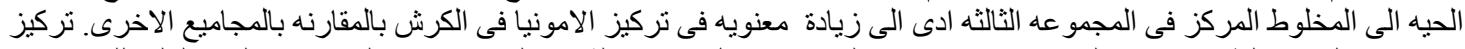

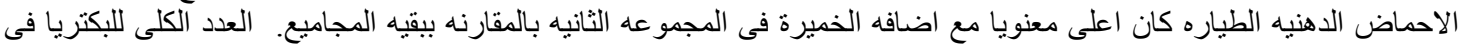

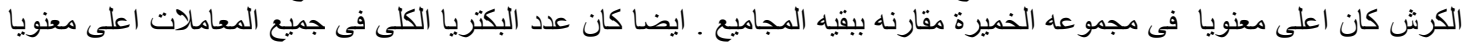

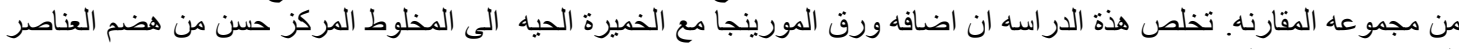

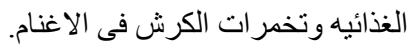

الكلمات الافتتاحيه:

اور اق المورينجاً: ، الخميرة الحيه ، الاغنام ، العناصر المهضومه ، تخمر ات الكرش 